Article

\title{
Enacting Transitions-The Combined Effect of Multiple Niches in Whole System Reconfiguration
}

\author{
Sibylle Bui ${ }^{1,2}$ (1)
}

check for updates

Citation: Bui, S. Enacting Transitions-The Combined Effect of Multiple Niches in Whole System Reconfiguration. Sustainability 2021, 13, 6135. https://doi.org/10.3390/ su13116135

Academic Editor:

Cécile Détang-Dessendre

Received: 13 April 2021

Accepted: 25 May 2021

Published: 29 May 2021

Publisher's Note: MDPI stays neutral with regard to jurisdictional claims in published maps and institutional affiliations.

Copyright: (C) 2021 by the author. Licensee MDPI, Basel, Switzerland. This article is an open access article distributed under the terms and conditions of the Creative Commons Attribution (CC BY) license (https:/ / creativecommons.org/licenses/by/ $4.0 /)$.
1 Ecodéveloppement, INRAE, 84000 Avignon, France; sibylle.bui@univ-cotedazur.fr

2 Groupe de Recherche en Droit Economie et Gestion, CNRS, Université Côte d'Azur, 06560 Valbonne, France

\begin{abstract}
The environmental and social issues caused by agricultural and food distribution practices call for a profound reconfiguration of the agri-food system. This paper is aimed at contributing to a better understanding of the way such a reconfiguration may be fostered. Building on recent developments of transition studies that analyze whole system reconfigurations, it proposes a pragmatist, whole system approach to examine the socio-political dimension of sustainability transitions. Based on the ethnographic and longitudinal study of a unique case of (territorial) agroecological transition in France, it identifies the mechanisms involved in a transition and the way actors enacted them. It characterizes required prior, incremental system changes, and stresses the role of multiple niches that influence simultaneously the various components of the agri-food system. From an action-oriented perspective, these results suggest that transitions may be fostered by: (1) supporting the diffusion of an alternative technological paradigm within the regime that niches may be congruent with; (2) stimulating the development of a diversity of radical innovations related to the various dimensions of the agri-food system and fostering their interactions with the regime; and (3) moving from a technology-driven approach of innovation towards an emphasis on organizational innovations that foster the rebalancing of power relations.
\end{abstract}

Keywords: sustainability transitions; agri-food system; agency; power; multi-level perspective; whole system reconfiguration; niche-regime interactions; transition governance

\section{Introduction}

In order to tackle the environmental, social, and health issues caused by agricultural and food distribution practices, the agri-food system urgently needs to be profoundly reconfigured to shift towards sustainability. This paper is aimed at contributing to a better understanding of the way such a shift may be fostered by examining the way actors may act on socio-technical developments and eventually trigger a sustainability transition.

The multi-level perspective (MLP) is a fundamental heuristic underpinning transition studies, which considers that societal functions such as food provision are fulfilled by systems made of co-evolving social and technical elements. The MLP conceptualizes transitions as system innovations, and it distinguishes three analytical levels: the regime, corresponding to the set of rules supporting the dominant socio-technical system, which maintains actors on a given technological trajectory and exerts strong lock-in effects; niches, small networks of actors developing radical innovations and testing new rules around these innovations; and the landscape, the exogenous socio-technical context actors cannot directly influence [1-4]. It suggests that various radical innovations are developed in niches, until one of them appears as the most promising, and that it is the interaction between this niche, the regime, and the landscape that possibly triggers a socio-technical transition. Over the past fifteen years, transition studies have provided inputs to policy reflection in numerous countries and industries (e.g., [5,6], and the incorporation of insights from a variety of disciplines and theoretical backgrounds into this heuristic has allowed for the refining of the several dimensions involved in transitions. However, due to the 
complexity of the processes involved, understanding "why and how some niches set in motion transformational change [ ... ] while others fail" [7] remains an unresolved challenge. To contribute to this understanding, this paper asks: how can actors at a local level have a transformative influence on socio-technical developments?

Transition studies have been criticized for focusing on technological dimensions [8] and overlooking the role of actors in transition dynamics $[9,10]$. Numerous contributions have then been made to shed light on agency (i.e., actors' capacity to act). Geels and Schot ([3], p. 414), building on Giddens' structuring theory [11], argue that actors may both reproduce and change the rules and invite analysts "to zoom in on actors". This invitation has paved the way for several refinements: Elzen et al. [12] analyze how normative pressure exerted by outsiders can influence regimes; Geels and Verhees [13] show how framing struggles between incumbent and alternative discourses performed on public stages impact cultural legitimacy; and other authors analyze the trajectories and roles of specific actors, including farmers (e.g., [14]), intermediary actors (e.g., [15]), and civilsociety (e.g., [16]). Various typologies have been proposed to analyze the role of actors in transitions (for a review, see [17]), and of their evolving interests, values, rationales, and strategies [18-20]. Answering calls to account for the inherent political dimension of socio-technical dynamics [21,22], Grin et al. [23] demonstrate that transitions imply change in power relations. Several conceptual frameworks have since been mobilized or created to analyze shifts in power relations [24,25], including by Avelino and Wittmayer [26], who claim analyzes should focus on levels of dependencies between actors, and Rossi et al. [27], who suggest transitions imply more nuanced power relations between the various actors of the socio-technical system. Furthermore, Wittmayer et al. [28] show that fundamental changes in the roles of actors and their inter-relations are a key feature of transition processes. Those various contributions fruitfully identify some specific dynamics and levers through which actors manage to influence some regime rules. Nevertheless, in a perspective of operationalizing the transition to sustainable food systems, a comprehensive review of the mechanisms involved in regime shifts and of the way actors manage to operate these mechanisms is still needed [29].

Recent research has addressed this gap by operating the complementary movement of 'zooming out', enlarging the focus to whole system reconfigurations. Geels's [30] longitudinal analysis of the UK passenger mobility system points out the importance of examining multiple regime dynamics (auto-mobility, train, bus, and cycling) and multiple niche-innovations simultaneously to give full account of the diverse interacting change mechanisms involved in socio-technical developments. McMeekin et al. [31] develop an approach for whole system analysis and produce a typology of change mechanisms based on the case of the low-carbon transformation of the UK electricity system. However, as stressed by these authors, the trade-off of this 'zooming out' strategy is the difficulty to conduct a sharp analysis of social change processes: the socio-political dimension of whole system reconfigurations has yet to be fully explored.

This paper is aimed at contributing to such exploration by looking at a unique case of agroecological transition in France, in the Drôme valley, to understand how actors can foster whole system reconfigurations. It is organized as follows. Section 2 develops an analytical framework to tackle agency in a whole system approach of sustainability transitions. Section 3 details the methodology designed to apply the framework to the Drôme valley case, as well as the analyzed material. Section 4 presents the socio-technical evolution of the agri-food system of the Drôme valley from 1970 to 2015 and evidence of whole system reconfiguration. Section 5 stresses the transition mechanisms that have allowed some actors to bring about a regime shift in this region. The concluding section synthesizes the paper's contributions and discusses their implications for an operationalization of sustainability transitions. 


\section{A Pragmatist, Whole System Approach to Tackle Agency in Transitions}

In line with Geels's [30] and McMeekin et al.'s [31] work, the present whole system approach reconnects with the MLP's systemic foundations to address: (1) multiple regime dynamics, meaning that, for the agri-food regime, all food chains and all production systems are included in the analysis; (2) multiple niche-innovations; and (3) multiple landscape dynamics that influence the agri-food regime.

This paper builds on Geels and Schot's definition of niche and regime as two analytical levels, corresponding to socio-technical configurations (i.e., heterogenous arrangements of coevolving social and technical elements) that differ in size and stability [3]. The regime is the dominant socio-technical configuration, stable and underpinned by a set of rules. Niches are smaller and less stable socio-technical configurations whose rules radically differ from the ones at stake in the regime. These definitions leave much space for interpretation. Depending on scholars' analytical choices, a technological evolution might be interpreted as an incremental change or as a regime shift [9]. The need for reflexivity in the empirical use of the MLP [32] is not always met, which has produced a number of studies focusing on innovations that do not radically diverge from the dominant system [33], mistakenly giving incremental innovations the status of niche and restricting transitions to the broad dissemination of an alternative technology with lower environmental impact. Examples in the agricultural sector are studies on innovations aimed at mitigating the environmental impact of intensive farming, which certainly induce changes in farmers' practices and at the system level, but actually contribute to the adaptation and reproduction of the unsustainable, dominant agri-food system.

Which rules are we talking about? How do we assess their radical nature? Despite being a key concept in the MLP, the notion of rules is rather imprecise and has hardly been operationalized [34]. Rules are "what lies underneath the activities of actors" ([1] p. 31) and encompass a wide variety of heterogeneous elements such as beliefs, social norms, world views, lifestyles, consumption patterns, users' expectations, technological paradigms, research agendas, heuristics, problem definitions, values, policies, regulations, and contracts $[1-4,8,35]$. This heterogeneity makes the empirical study of rules difficult. The proposition here is to consider that what lies underneath the actors' activities is their representations, and that their activities consist of a set of practices and interactions. On this basis, saying that niches' rules radically differ from the regime's amounts to saying that the representations, practices, and/or interactions developed by niche actors deviate (i.e., engage in an antagonistic dynamic [24]) on most points from those in the regime. Representations are here broadly defined, encompassing all elements that influence actors' practices and interactions: the values they uphold; the way they define their role (their objectives, missions, strategies, and the criteria they choose for evaluation) and the others' roles; the problems, issues, and solutions they identify; their vision of the future; and their vision of agriculture, of rural development, of organic farming. The notion of representation thus encompasses the various variables that previous work on agency in transitions have focused on and proven useful (Section 1), which allows grasping the complex and evolving rationality of actors. Practices are the actual practices implemented by the actors, the building blocks of their activities that contribute to the societal function under study. For the present analysis, the practices directly and indirectly related to the production, buying, selling, storing, transportation, processing, marketing, and consumption of food products that are implemented by the various actors of the agri-food, socio-technical system will be considered. Practices are both constituent parts of the socio-technical system and proxy indicators of the actors' implicit representations. As they reflect the actors' scope of action, they are also proxy indicators of the power relations at stake. Interactions are all the formal and informal relations between actors of the socio-technical system, e.g., collaboration, coordination, knowledge exchange, and discussion.

Geels ([1] p. 31) recommends that "the analyst should first demarcate her object of analysis and then operationalize the analytical levels from the $M L P^{\prime \prime}$. Inferring the analytical levels from the analysis allows avoiding two other epistemological pitfalls, which I believe have so 
far obscured the role of actors in transitions. The first pitfall is to define social groups ex ante. According to Pinch and Bijker [36], a social group is a group of individuals who share the same set of meanings attached to an artefact. It may therefore be convenient to distinguish various social groups within a social category, if the individuals composing this category do not share the same set of meanings. The MLP theoretically bases analyses on social groups [37], but actors are generally considered in monolithic, pre-determined categories (e.g., producers, consumers, public authorities, firms) (for a review of categories and typologies in the literature, see [28]). Consequently—and this is the second pitfallniche and regime actors are designated ex ante, based on whether they do or do not use an alternative technology or contribute to its development. For instance, scholars working on organic farming considered organic actors as niche and non-organic actors as regime (e.g., $[38,39])$. Yet farmers' motivations to convert into organic farming are diverse; some convert for reasons of ill health or economic expediency, while others are engaged in a philosophical reflection on mankind's relation to nature. The technical and marketing options they choose relate to these motivations and have different transformative potentials [14]. Various forms of organic farming coexist, ranging from highly diversified and self-supporting farming systems to highly specified and input-intensive farming systems. These farming systems are implemented by diverse social groups, embedded in various supply chains, and supported by different networks of actors-some contributing to the reproduction of the system and others inventing, for instance, new distribution channels or consumption patterns. To account for this complexity, the proposition is to conduct a 'flat' longitudinal analysis, i.e., without defining social groups or analytical levels ex ante, and to infer them from the empirical findings.

In a whole system approach, the analysis of socio-technical dynamics takes into account all the actors of the agri-food system (i.e., involved in land allocation, input supply, agricultural production, processing, retail, consumption, research, development, education, public policies and regulation). It is performed through the prism of the three variables presented above: (1) these actors' technical, social, marketing, and/or organizational practices; (2) their representations; (3) their interactions. These variables allow identifying groups of individuals and organizations that share common sets of representations and whose practices are aligned; they allow characterizing distinct sociotechnical configurations (Figure 1). The regime is the dominant configuration, i.e., the largest one. Niches are alternative configurations, composed of actors whose practices and representations radically diverge from the regime.

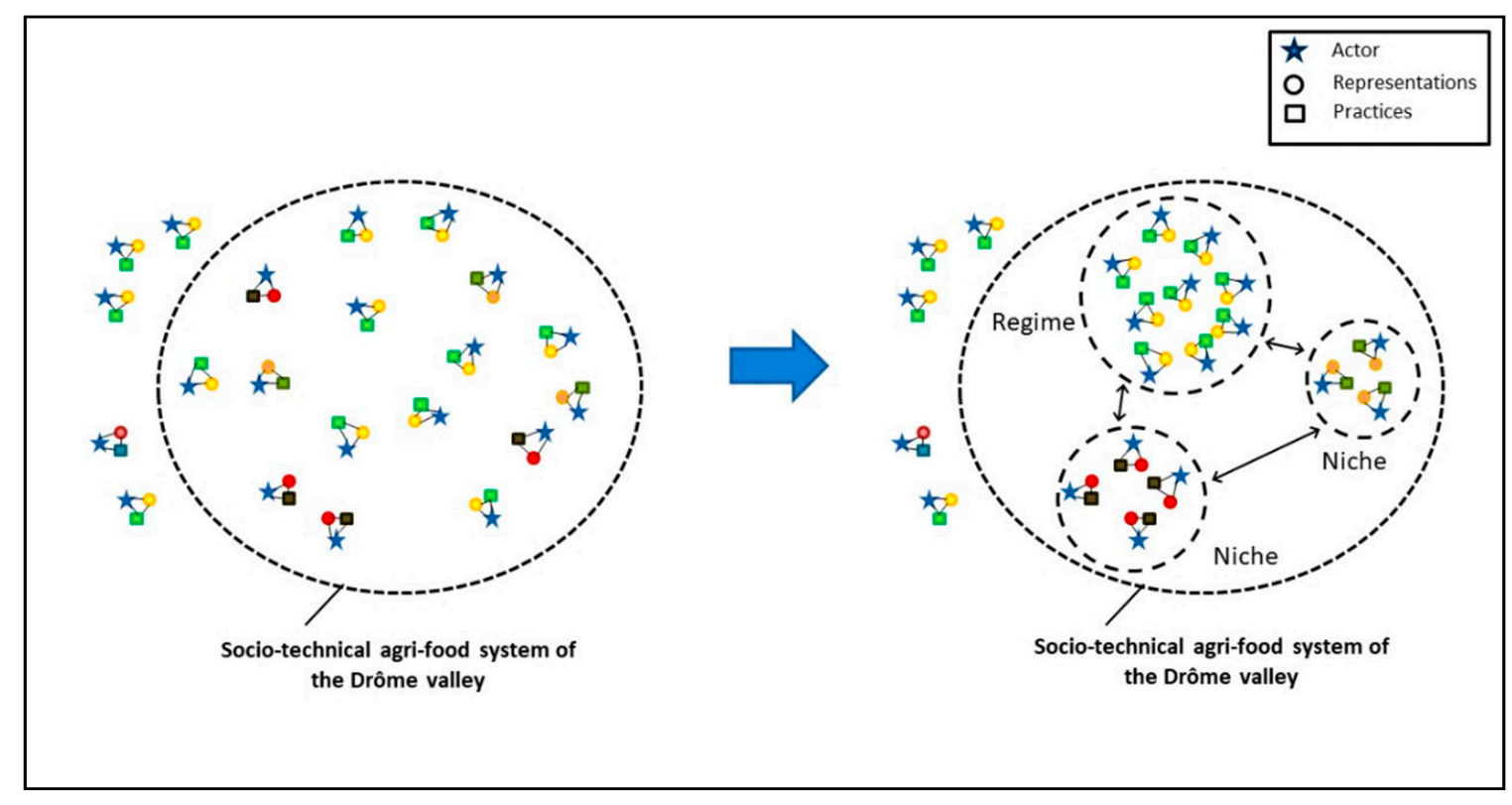

Figure 1. Inferring regime and niche levels from empirical results. 
To analyze the interactions between these socio-technical configurations, as well as the associated changes in stability and power relations, the concepts of enrolment and interessement from pragmatist sociology are mobilized (Table 1). It should be specified that both concepts, as well as the 'flat' empirical approach, are incorporated as analytical tools to avoid the above-mentioned pitfalls, with no intention, however, to question the multi-level conceptualization.

Enrolment is the process by which an actor successfully redefines other actors' roles, goals, orientations, motivations, or interests [40]-i.e., their representations-resulting in the building and breaking of alliances. The founders of the MLP already mobilized this concept to describe processes of niche development, and despite the ontological controversies this generated [8,9,41], further combining pragmatist sociology and MLP has proven relevant to analyze niche-regime interactions $[42,43]$. The originality of the present approach is twofold. First, it considers the building and breaking of alliances in a whole system approach instead of taking as a starting, focal point one single niche innovation. This enlarged perspective on enrolment processes allows characterizing changes in power relations and mechanisms of (de)stabilization of socio-technical configurations. As their set of alliances enlarges, actors grow more powerful. As more actors are enrolled in one sociotechnical configuration, the latter stabilizes [44] due to the alignment of the representations of the various actors involved [40], as well as of their practices. In turn, other configurations are destabilized as they are deprived of those actors and of their human, material and financial resources, and the remaining actors are weakened. The second originality of the present approach is to incorporate the concept of interessement. Interessement is the process by which one actor enforces others into new roles and activities [45]. In the present approach, it is used to highlight the more subtle changes in power relations that occur when one actor enforces changes in practices and representations of another actor, but without the practices and representations of both actors becoming aligned. Although the socio-technical configuration the enforced actor is part of is not destabilized, the set of practices and representations it is composed of is (partially) modified. Hence, the concept of interessement contributes to a more comprehensive view of socio-institutional changes, emphasizing novel aspects of agency. Table 1 presents how the key concepts, variables, and mechanisms of the analytical approach are linked.

Table 1. Articulation of the key concepts, variables and mechanisms.

\begin{tabular}{|c|c|c|c|c|}
\hline & \multirow[b]{2}{*}{ Representations and Practices } & \multirow[b]{2}{*}{ Interactions } & \multicolumn{2}{|c|}{ (De)stabilization/Power Relations } \\
\hline & & & $\begin{array}{c}\text { Socio-Technical } \\
\text { Configuration A Belongs to }\end{array}$ & $\begin{array}{c}\text { Socio-Technical } \\
\text { Configuration B Belongs to }\end{array}$ \\
\hline $\begin{array}{l}\text { Enrolment } \\
\text { of A by B }\end{array}$ & $\begin{array}{l}\text { Radical change in } \\
\text { representations and practices-A } \\
\text { and B's representations and } \\
\text { practices become aligned }\end{array}$ & New alliance & $\begin{array}{c}\text { Destabilization/Less } \\
\text { favorable balance of power }\end{array}$ & $\begin{array}{c}\text { Stabilization/more } \\
\text { favorable balance of power }\end{array}$ \\
\hline $\begin{array}{c}\text { Interessement } \\
\text { of A by B }\end{array}$ & $\begin{array}{l}\text { Change in some of A's } \\
\text { representations and practices } \\
\text { without A's and B's } \\
\text { becoming aligned }\end{array}$ & No change in interactions & $\begin{array}{c}\text { No destabilization/no } \\
\text { change in power relations }\end{array}$ & $\begin{array}{c}\text { No stabilization/no change } \\
\text { in power relations }\end{array}$ \\
\hline
\end{tabular}

\section{A Qualitative and Inductive Methodology}

This whole system approach was used to analyze the case of the Drôme valley, a rural territory located in southeast France (around $2200 \mathrm{~km}^{2}, 102$ municipalities, 54,000 inhabitants), chosen for its unique development of organic farming (OF). There, OF represents one third of farmers, versus $6 \%$ at the national scale, and involves a large diversity of local actors, including processing, marketing, and retail organizations, as well as local authorities who elaborated an ambitious local development policy called Biovallée. This suggests that, locally, actors have built a new socio-technical system around OF, which was treated as a research question when fieldwork started. 
The research is conducted at the local scale to ensure the feasibility of combining a 'zooming out strategy' with a detailed analysis of socio-political aspects. Extending Lawhon and Murphy's argument that focusing on dynamics through which regimes that are differentially embedded in a diversity of local contexts is necessary to understand "why progress towards sustainability proceeds in a spatially uneven manner" ([46] p. 362), the assumption here is that an in-depth whole-system analysis of such an 'unlocked' form of embeddedness may provide generic insights on agency. The local agri-food system is hence approached as a local variation of the regime and considered in its dynamic, multi-scale (local, regional, national, international) dimension.

The socio-technical evolution of the local agri-food system was analyzed from the late 1960s, when OF first appeared in this valley, until 2015. In a whole-system approach, all the local actors who have an influence on, or aim to influence, agri-food dynamics were taken into account: farmers, consumers, local authorities, the local agricultural school, civil-society organizations, and the main agricultural economic operators (input suppliers, processors, farmers' marketing cooperatives and other agri-businesses, small and corporate food retailers, restaurants, canteens). All food chains of the valley were included: goat and laying hen rearing, aromatic and medicinal plants, fruits, vine, cereals, and vegetable growing. As some components of the agri-food system only exist at other scales, also included were departmental and regional organizations such as farmers' associations, research and experimentation stakeholders, wholesalers, and the Chamber of Agriculture-referred to as 'the Chamber' from this point on (Chambers of Agriculture are professional, agricultural associations and they are the main players for training and extension services in France). Where they existed, alliances with more remote actors were also taken into account. The broader dynamic context (landscape level) was accounted for at regional, national, European, and international scales in terms of agricultural and rural development policies, economic environment and agricultural prices, and cultural changes related to environmental and agricultural issues.

The practices, representations, and interactions of the above-mentioned actors were examined (illustration for some of them in Table 2) longitudinally. On this basis, different socio-technical configurations, composed of actors whose practices and representations are aligned, were identified.

Table 2. The three sets of variables and examples of collected data.

Farmers: agricultural, training, experimentation, and marketing practices

Farmers' cooperatives: infrastructure building, investments, experimentation programs and designs,

HR management (sales commission, coupling of technical and commercial functions), purchasing and marketing practices, organization of grain collection and share of $\mathrm{OF}$

Practices Local authorities: design, content, implementation, and assessment of Local development and Agricultural policies; distribution of financial, material, and human resources Chamber of agriculture: content, speakers, and target population of training courses; design and experimentation programs; agricultural and rural development programs; financial, material, and human resource allocation

Retailers: sourcing, buying, organizational and marketing practices

Representation of their own role (their objectives, missions, strategies, and the criteria they chose for evaluation), and of the others' roles; the problems, issues, and solutions they identify; their vision of the place and future of agriculture, of rural development, of conventional and alternative farming, of the "good" agriculture and agri-food system.

Representations

Interactions
Presence/absence of relations between actors, nature (e.g., supplier/client or subsidized organization/funder) and functioning (decision-making processes).

Fine granularity was preferred to homogeneous treatment, which is why not all actors were equally considered. First, a few key actors were examined in-depth: the two community of municipalities of the valley that elaborated the flagship project Biovallée (2009-2015), which targeted 50\% OF; a farmers' cooperative, which gathers two thirds of local farmers and is $70 \%$ organic-a unique positioning for a French grain cooperative; 
and four initiatives shown, during the first year of fieldwork, to play a pivotal role in reconfiguration dynamics. On this basis, the trajectories (i.e., the co-evolution of the interdependent practices, representations, and interactions) of each of these actors or networks were thoroughly analyzed. Through the lens of these trajectories, data on the practices, interactions, and representations of the other actors was collected. Using writing as an analytical process [47], these trajectories were then weaved together into a monograph of the local agri-food system.

Data collection was based on an ethnographic study and archival work. The ethnographic study (2012-2015) includes observations of 59 interaction situations to analyze representations and interactions in present time (e.g., agricultural committees and working meetings of local authorities; training sessions organized by the Chamber and the Organic farmers group; project steering meetings, general meetings, and board meetings of various local, departmental, and regional organizations; public events) and 24 comprehensive interviews to obtain actors' interpretation of past and present events. Thirty interviews, conducted in 2011-2013 by colleagues, were also integrated into the analysis (Table 3). Such a high number of interviews is justified by the diversity of actors included in the whole system approach and the length of the study period.

Table 3. The three surveys included in the analysis and their list of interviewees.

$$
\text { Interviews conducted by the author }
$$

2012-2015: Longitudinal analysis of the agroecological transition in the Drôme valley

Farmers; current and former elected officials and agents of local authorities; current and former advisors and elected officials of the Chamber and farmers' associations; members and staff of farmers' cooperatives; members, administrators, and coordinators from civil society organizations

Interviews from other surveys

Former staff and director of the local agricultural school; advisors of the Chamber and Organic farmers group; farmers; founder of the aromatic and medicinal plant cooperative; founders and directors of a farm incubator and of a cooperative, organic grocery store; fruit traders; current and former staff and elected official of local and regional authorities

2011: Longitudinal analysis on the development of organic market gardening in the Drôme valley

For the purpose of the longitudinal analysis, an extensive documentary work was also completed. More than 700 documents dating from 1969 to 2015 were qualitatively analyzed (project documents; guidance documents; minutes of general meetings, board meetings, and working meetings; minutes of agricultural committees; of steering committees; articles from general and specialized press; newsletters and communication tools, grey literature). This was done in order to gather data on past controversies, negotiations, conflicts, and projects, including failed ones, as well as quantitative data such as agricultural statistics, demographics, national and European financing, local and regional budget allocations, and the development of national and international agricultural prices. Due to the heterogeneity of the data sources and of the data itself, manual coding was preferred to computer processing. Triangulating multiple types of data allowed deconstructing the reinterpretation of past events actors may make in present time and retracing the processes of socio-technical evolution as precisely as possible. The resulting analytical narrative is summarized in the next section (in which, unless indicated otherwise, all data and analyses come from the author's Ph.D. thesis [48]).

\section{The Agroecological Transition in the Drôme Valley (1969-2015): A Two-Step Process}

"[In the agricultural secondary school], I was formatted, like all the kids back then, that is to say to productivism, farm expansion [ ... ] and fertilizers, agrochemicals, etc. So, we came out very, very formatted. And when I settled into farming, I was in that frame of mind. And I remember, I had settled for two months I think, and my uncle [...] 
came to see me, and he came with a fertilizer salesperson. In the countryside, dealers always come along with a farmer because it appears like a guarantee. [ . . . ] He said to me: "Oh, this land hasn't seen fertilizers for a long time, you should buy NPK, potash, nitrates and all. Otherwise, you'll have no grass for your animals". [ . . ] Neither did the veterinary know about phyto[therapy] nor veterinary homeopathy, so we did work with antibiotics, it was extremely traditional. On top of that came the farm technicians, who were totally in a vision ... when you settled, to get the Young Farmer Grant [ ... ] you had to fit in a framework for investment, to buy equipment, to invest tremendously. So, I was totally into this vision [ ... ] with the advice from the technician of the Chamber of Agriculture, with the training of the agricultural secondary school. And the social context too, because it is just as strong, as significant as the good advice from professionals." (Former breeder, who settled into farming in the Drôme valley in 1972)

As illustrated by this producer's testimony, in the 1970s in the Drôme valley, one single socio-technical configuration gathered producers, veterinary and extension services, agrochemical industries locally represented by independent salespersons, and the agricultural school around a vision of "good agriculture" based on mechanization and the intensive use of chemical inputs. This socio-technical configuration also included supply and marketing farmers' cooperatives and local authorities. As such, it can be inferred that, as elsewhere in France and western Europe, the local agri-food system was aligned with the paradigm of "Agricultural modernization". As it combined a large set of heterogeneous elements, this sociotechnical configuration was highly stable.

In this socio-technical configuration, the agricultural school and the Chamber played a major role because their strategies and activities strongly shaped those of the other actors. Local authorities (i.e., the two communities of municipalities of the valley) played a minor role, limited to the implementation of national agricultural policies, that encouraged agricultural restructuring to expand the size of farms, mechanization, intensification, and the development of income-generating products to maintain farming activities and thereby combat rural depopulation.

It is in this context that OF emerges. It is developed both by innovative newcomers and local farmers [49] who feel at odds with intensification and convert to OF to translate their set of values into a set of practices [50]. Most newcomers belong to the second "backto-the-land" movement, which took place after 1975 in France, and yearn for living in the countryside and entering the existing social and economic networks [51]. They join traditional agricultural organizations such as farmers' cooperatives and experimentation groups, which locally fosters the development of OF.

\subsection{Step 1: Differentiation of Two Configurations within the Regime}

The creation of the organic label in 1985 incites the four local farmers' cooperatives located in the upstream part of the valley called Diois, to elaborate a project, to structure organic supply and marketing chains for organic farmers to access the inputs they need, and to add value to their products. To cover the investments for infrastructures, the cooperatives need to increase the share of organic sales (OF only represents a few percent in the early 1990s), so the project includes conducting experiments to develop their staff's advisory skills.

The cooperatives convince the community of municipalities of Diois (CCD) to support their project. In a context where rural development policies take a quality turn [52], and where locally depopulation is a major issue, OF appears as a way to maintain agriculture by better rewarding producers and creating a positive image of the area. This alliance is critical as it allows benefiting from the support of departmental authorities (in France, departments and regions are the next administrative levels above communities of municipalities) that have direct connection with EU agents and manage to get a special envelope from the European Union. These credits act as a driving force: the cooperatives receive funds that national and regional institutions would not have granted otherwise, and the high rates of funding incite them to develop a more ambitious program. The initial six-year project 
is deployed for ten years and gives visibility to Diois, which becomes recognized as an innovative area at the national scale. The influx of funding has other symbolic impacts: it increases the legitimacy of organic farmers, who stop being perceived as eccentrics, and the credibility of $\mathrm{OF}$ as a way forward for the whole local agriculture. This translates into the conversion of Diois' agricultural leaders and, consequently, of more farmers. Additionally, it fosters the enrolment of CCD, as indicated by the title of its guidance document in 1995: "Organics, the future of Diois", and by its recruiting of the coordinator of the project in the late 1990s, which proves the institutionalization of this vision of OF and of the role of CDD as a legitimate stakeholder in relation to agricultural matters.

The inter-cooperative project has a structuring effect both technically and commercially, and OF reaches $10 \%$ in 10 years. It also has a significant impact on the activities and representations of the other actors of the dominant system (interessement). To receive funding from the inter-cooperative project, the Chamber starts providing advisory services to organic farmers (which it had refused to do up to that point), and the agricultural school starts proposing training on OF: OF, which had hitherto been an invisibilized model to the major players, is put on their agenda. In turn, in the 2000s, in the Val de Drôme downstream area, where farming is more intensive than in Diois, many farmers, processors, and other cooperatives also start to engage in organics. This is of course also fostered by changes at the landscape level consisting of an increasing demand for organics, but the dynamics is much stronger in the valley than elsewhere, and the detailed analysis [48] shows that it results directly from the shift in activities and representations of the major agricultural players of the area.

This momentum is maintained with the combined actions of various actors. For instance, in the early 2000s, the grain cooperative invests in a seed platform to produce organic seeds adapted to local conditions (an imperative need no longer fulfilled by seed-bearers). It merges with the supply cooperative and redefines its advisors' routines, disconnecting their salary from product sales, focusing their activity on extension services and developing their skills on organics (trials on high value crops and advice on farm seeds to foster farmers' self-sufficiency). Additionally, it buys products that are farmed organically but not yet certified at the price of organic products, to support farmers who chose to convert (during the first three years of conversion, organic farmers are not allowed to sell their products as organics, which is a major obstacle given that conversion is generally associated with significant yield loss). The other cooperatives and CCD also continue supporting the development of OF (for a detailed analysis, see [48]). These combined actions allow OF to rise from 10 to $25 \%$ in a few years in Diois.

As OF develops, its image evolves. The Chamber starts acknowledging its technical interest by recruiting new organic advisors, and from 2007 on, organizing a professional fair on alternative and organic techniques. This legitimizes $\mathrm{OF}$ as a sound technical model and fosters conversions in other parts of the valley. However, although the Drôme Chamber becomes the number one for $\mathrm{OF}, \mathrm{OF}$ remains a marginal issue in its guidance documents: recruiting organic advisors is not related to a profound shift in representations, it is a way to preserve its hegemony in the local agri-food system (interessement).

All organic chains of the valley experience a boom in the 2000s. The aromatic and medicinal plants chain is particularly emblematic. The outstanding quality of its products achieves international recognition, and companies settle in the valley to process these products, generating hundreds of employment opportunities [53]. Consequently, the community of municipalities of Val de Drôme (CCVD) starts considering OF as an economic drive (interessement). It proposes CCD to elaborate a joint project at the scale of the whole valley, taking organics as the foundation of an endogenous development. In 2008, they seize a regional funding opportunity that calls for innovative pilot projects with an integrated approach to sustainable development. This encourages them to develop a more ambitious and integrated project: the Biovallée program, aimed at making the Drôme valley the European region of reference for sustainable development. The objectives for agriculture are far more ambitious than the national goals prevailing at that time (Table 4) and put OF 
to the fore as a model; CCVD has been enrolled and its vision and policies are now aligned with those of CCD. In parallel, the agricultural school, threatened with closure, makes a strategic move towards OF. It decides to specialize in organics, and it eventually does avoid closure.

Table 4. Ambitious objectives of the Biovallée program in the food and farming sector.

\begin{tabular}{ccc}
\hline & National Objectives & Biovallée Objectives \\
for 2018/2020 & $\mathbf{2 0 1 5}$ & $50 \%$ \\
\hline \% OF & $20 \%$ & $-50 \%$ \\
\hline Reduction in pesticide use & $-30 \%$ if possible & $80 \%$ \\
\hline
\end{tabular}

In summary, a first transformation of the local agri-food system starts in the early 1990s. A new socio-technical configuration emerges within the regime as a result of the changes in practices of some farmers and of the inter-cooperative project. This new sociotechnical configuration progressively aggregates increasing social and technical elements and becomes more stable. The practices and representations of the various actors of the local agri-food system co-evolve for two decades. This results, in the late 2000s, in the regime being composed of two socio-technical configurations, which partially integrate the proposal of OF (partially in the sense that neither embraces the proposal of OF in all its technical, environmental, economic, and social dimensions, as it is defined by the International Federation of Organic Agriculture Movements or in the Charter of the French organic movement). Of the two configurations, one is aligned with the paradigm of "Agricultural modernization", and the other gathers farmers, the Diois cooperatives, the two local authorities, and the agricultural school, around a new technological trajectory and a set of representations that can be referred to as the paradigm of "Ecological modernization". "Ecological" because OF is considered as a way forward for all local agriculture, and "modernization" because it does not question the functioning of the global dominant system (without reference to the ecological modernization literature). This is the first step towards a further, more profound reconfiguration of the local agri-food system.

\subsection{Step 2: Development of a Third Configuration Outside and in Interaction with the Regime}

The Biovallée program is launched in 2009, but local authorities face difficulties regarding its implementation. Their strategy is to stimulate strong growth in OF through the installation of agro-industries, encouraging a cluster dynamic. They also have a partnership with the Chamber to develop training and create an experimental platform on $\mathrm{OF}$ and alternative farming techniques. However, collaborations with mainstream actors fail to sustain this strategy, with several projects aborting. For instance, the Chamber creates an experimental platform, but the experiments are designed following conventional principles (input-intensive monocrops, highly mechanized technical operations, etc.) and consequently do not answer organic farmers' needs for technical references. Additionally, despite strong demand stemming from the Biovallée program, the Chamber decides not to take charge of organizing food chains for school catering. A distribution platform is created by a major distributor of organic products, with strong financial support from Biovallée, but closes after two years because the company considers school catering as not being profitable enough. Another objective of Biovallée is the creation of farm incubators in economic activity areas for developing small-lot, high added value agriculture. Encouraging young farmers' setting-up is one of the Chamber's missions, and the fact that it undertakes no action in relation to that objective proves again its resistance to the vision of the Biovallée program.

It is in this context that local authorities are asked for funding by actors that develop other ways of supporting OF:

- Carline, a cooperative organic store willing to increase its share of local products; 
- Agricourt, a community association gathering parents and farmers willing to create a distribution platform to supply school canteens with fresh, local products from small-scale agriculture;

- The departmental goat farmers' union, willing to develop an innovative experimental program on herbal veterinary treatments (phytotherapy) in collaboration with a veterinarian and a pharmacist;

- Compagnons de la Terre, a community association already running a small, organic farm incubator in the area and gathering ex-employees of the agricultural school, farmers, and integration associations, which is asked by local authorities, after the Chamber declined, to create a farm incubator for Biovallée on a 16-hectare farm they had newly acquired for that purpose.

Thanks to Biovallée funding, these initiatives develop. Carline supports the emergence or growth of various local organic food chains (e.g., meat, cheese, flour and bread, vegetables) by setting prices in cooperation with local producers, applying lower margins to local products (and even lower margins to new entrants in farming), investing in equipment (e.g., refrigerated showcases) and infrastructure (purchase of a $160 \mathrm{~m}^{2}$ retail space), and developing projects to better coordinate (via pooled cropping plans or equipment) and enhance the technical skills of the small-scale farmers it works with. Thanks to these developments, it manages to supply $10 \%$ of the local population with organic products from local and small-scale farmers, based on shared governance between consumers, producers, and its employees, who jointly design an alternative economic model and its Ethics charter. This leads it to gradually consider itself as a legitimate player in local development. This representation is now institutionalized, as it became a member of the CCD agricultural committee, where local agricultural policies and grant allocations are discussed.

Agricourt also supports the growth of local food chains, both organic and non-organic, with the creation of a distribution platform. It started in the President's garage with a private vehicle, and now has dedicated premises with a cold room and refrigerated lorry that supplies nurseries, schools, and private and company restaurants in the valley. Shared governance between consumers, producers, processors, and restaurants allows the development of fair and ecologically-sound marketing practices (e.g., prices and cropping plans collectively discussed, long-term agreements, market price list displaying only local products, partnership with an organic cooperative sharing a similar Ethics charter to complement local production when lacking), thanks to which, $60 \%$ of the meals served in the schools of the valley are prepared with local products from small-scale, mostly organic, fairly remunerated farmers. By comparison, during the same period in France, $25 \%$ of school canteens propose organic products, generally once a month $(2 / 3)$ or once a week $(1 / 3)$, and only half of these canteens report favoring local food chains (Agence bio, 2015).

In the goat phytotherapy project, farmers make, test, and collectively assess treatments made from on-farm resources, to explore solutions to technical bottlenecks they encountered. The goat farmers' union turned to Biovallée after its project was rejected by the regional experimentation committee, which considered that phytotherapy was not a promising prospect. Despite certain reservations about the scientific soundness of the project, Biovallée funds were granted. The fact that none of the funding dedicated to research in the Biovallée program had been used was certainly an important factor. The project generated new knowledge on herbal treatments and interested FIBL, a worldleading research institute on OF. The resulting partnership brought credibility to the project and legitimacy to the topic and eventually lead to its integration into the regional research agenda by the regional experimentation committee, as well as into the national training offer (the project served to create a training module on phytotherapy provided by the national agricultural training agency).

Compagnons de la Terre supported a dozen new entrants in farming, with professional guidance and provision of land and farm equipment, supplemented as needs arose by storing, processing, and marketing facilities. Then, acknowledging incubated young farmers' persisting difficulties to access land due to rejection by conventional farmers of 
both OF and new entrants in farming, they also built, together with CCVD, a new system for farmland management: a public land tenure fund, which favors the setting up of organic new farmers and enables them to take ownership of the farmland after two years of testing their activity. This farmland management system is implemented in coordination with SAFER, the Land Use and Rural Settlement Agency.

All four initiatives can be considered as socio-technical niches, as they are small networks of actors that develop new rules and practices that radically differ from the regime's. The analysis of their trajectories, which can only be roughly summarized here to conform with the format of an article (for a more detailed analysis of the initiatives' trajectories, see $[42,48])$, shows that the coevolution of practices, representations, and interactions within each niche and in interaction with local authorities leads to the construction of alternative models (economic for Carline and Agricourt, land management for Compagnons de la Terre, and related to animal-health management for the goat farmers' union) and of radically alternative visions of food and farming issues, as well as of the associated network of relevant actors. This set of representations can be referred to as the paradigm of "Radical ecologization", given that its representation of good agriculture is totally different from the one in the dominant paradigm. In this setting, good agriculture is a peasant, small-scale, autonomous agriculture, making little or no use of chemical inputs while being respectful to the environment. It produces healthy food, offers good working conditions for farmers and workers, and implies reconnection and empowerment of consumers and producers. These niches have little interactions; the paradigm of "Radical ecologization" is supported by a network as conceived by Thomas Hughes [54]: a seamless web.

By receiving awards (from Fondation de France for Compagnons de la Terre and Fondation Crédit Coopératif for Agricourt) and support from international institutions (from FIBL for the goat farmers' union), as well as a lot of media attention (Figure 2), these initiatives help legitimize the locally controversial Biovallée program.

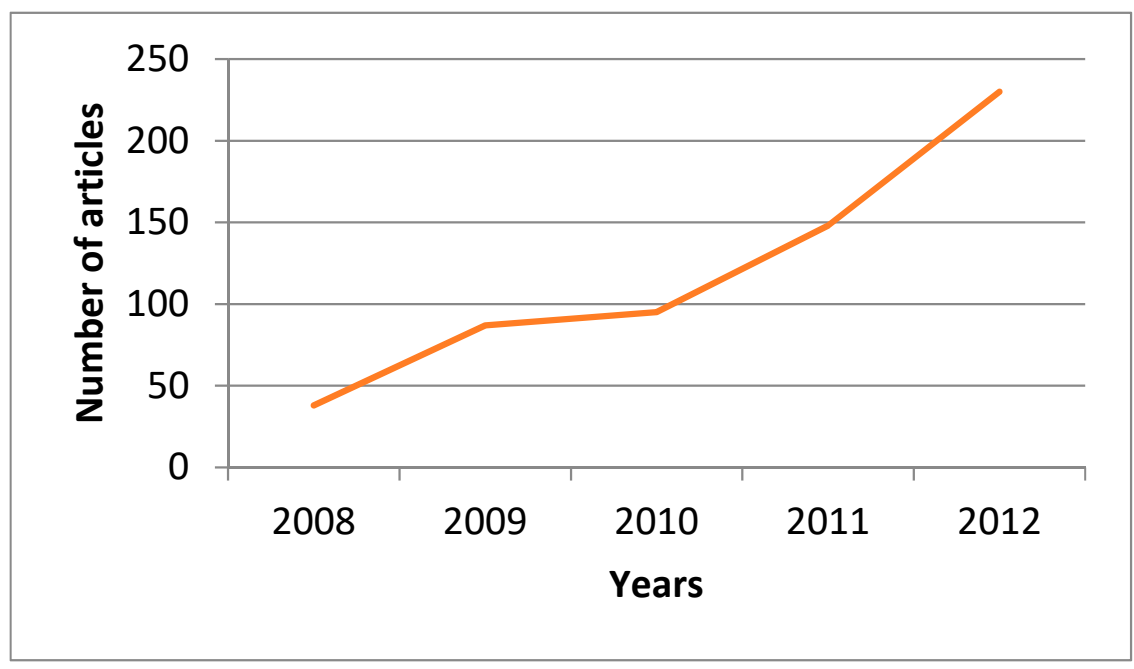

Figure 2. Number of articles published in the departmental, regional, and national press on the Biovallée program and its flagship projects (data source: CCVD Dpt of agriculture).

Contrasting with the disengagement of incumbent business and agricultural actors, these niche initiatives bring about solutions that contribute to the Biovallée objectives and demonstrate their feasibility-this was contested by many conventional agricultural actors, as was their relevance for the development of the area. The values and representations they convey are gradually shared by a wider range of local actors, including local authorities. A shift in discourse can be noticed in 2013: while they had, up to that point, promoted an organic cluster's dynamic based on the development of agro-industrial organic food supply chains with the intention of exporting food products from the valley, as well as promoting the use of organic or local products indifferently in school canteens, local authorities start 
advocating the use of fresh, local products from small-scale farmers (who are mostly but not exclusively organic) in school canteens, the relocation of the food system, and the reconnection between its various actors. This creates a conflict with the Chamber, whose representative, opposed to this vision, claimed loudly during one Biovallée agricultural committee that "agricultural policies must be in the farmers' hands!" and almost slammed the door.

The agricultural school is also deeply influenced. In the same period, it develops several modules on farm autonomy (farm-saved seeds, animal phytotherapy, etc.), in line with the "Radical ecologization" paradigm.

Further fundamental changes come about within the regime. In the socio-technical configuration fostering "Ecological modernization", the cooperatives continue their technological trajectory. For instance, in 2008, the local grain cooperative sets a target of $100 \%$ organics. At this time, organic crops represent $30 \%$ of the collection but generate $45 \%$ of the revenue, so in a competitive environment where small cooperatives tend to disappear [55], OF represents a solution for local farmers to keep control of their cooperative tool. It initiates the creation of a cooperatives' union for cereals marketing with neighbor cooperatives, allowing it to manage larger volumes and improve its knowledge and bargaining power in the market of organic cereals. It then engages in a strategy of downstream vertical integration, investing in a feed-mill that it turns to an organic mill to process its members' production, and in an organic egg-firm that valorizes the feed produced in the mill to ensure that added-value is distributed to the farmers. It does not intentionally seek to change the dominant system (most grain and eggs are sold in long circuits), yet it creates new practices and new forms of coordination that give farmers and their cooperative a greater control of the supply chain.

Thanks to their alliance in the Biovallée program, the two local authorities increase their budget three-fold for agriculture and thereby strongly enhance their capacity to orient the other actors' activities, bringing about critical changes in the dominant sociotechnical configuration related to the paradigm of "Agricultural modernization". The Chamber, whose budget significantly depends on project financing, is forced to actively contribute to the development of $\mathrm{OF}$ and to the Biovallée objectives, despite the ongoing conflict with local authorities. It works with the cooperatives on the testing of organic varieties, supports farmers who wish to convert, and organizes demonstration days and training sessions on organic techniques. On one of these demonstration days, funded by Biovallée, a local company of agricultural machinery showcases self-engineered equipment for mechanical weeding; various local actors join the dynamics around $\mathrm{OF}$, and the artefacts and practices they build foster interessement and enrolment of more farmers. This further legitimizes OF and provokes a massive adoption of some OF practices by conventional farmers. For instance, nowadays 50\% of all local grain farms use mechanical weeding instead of chemicals.

In summary, enrolment processes allowed for the emergence and development of two alternative socio-technical configurations within the local agri-food system: one within the regime, mainly driven by farmers' cooperatives and aligned with a paradigm of "Ecological modernization", and one outside the regime, driven by several niche initiatives and aligned with a paradigm of "Radical ecologization". They lead to the alignment of the visions and practices of many actors with these two alternative paradigms, which in turn, through interessement processes, caused OF to be placed on the agenda of all local agri-food actors and to become a structuring element of the local agri-food system (Figure 3). 


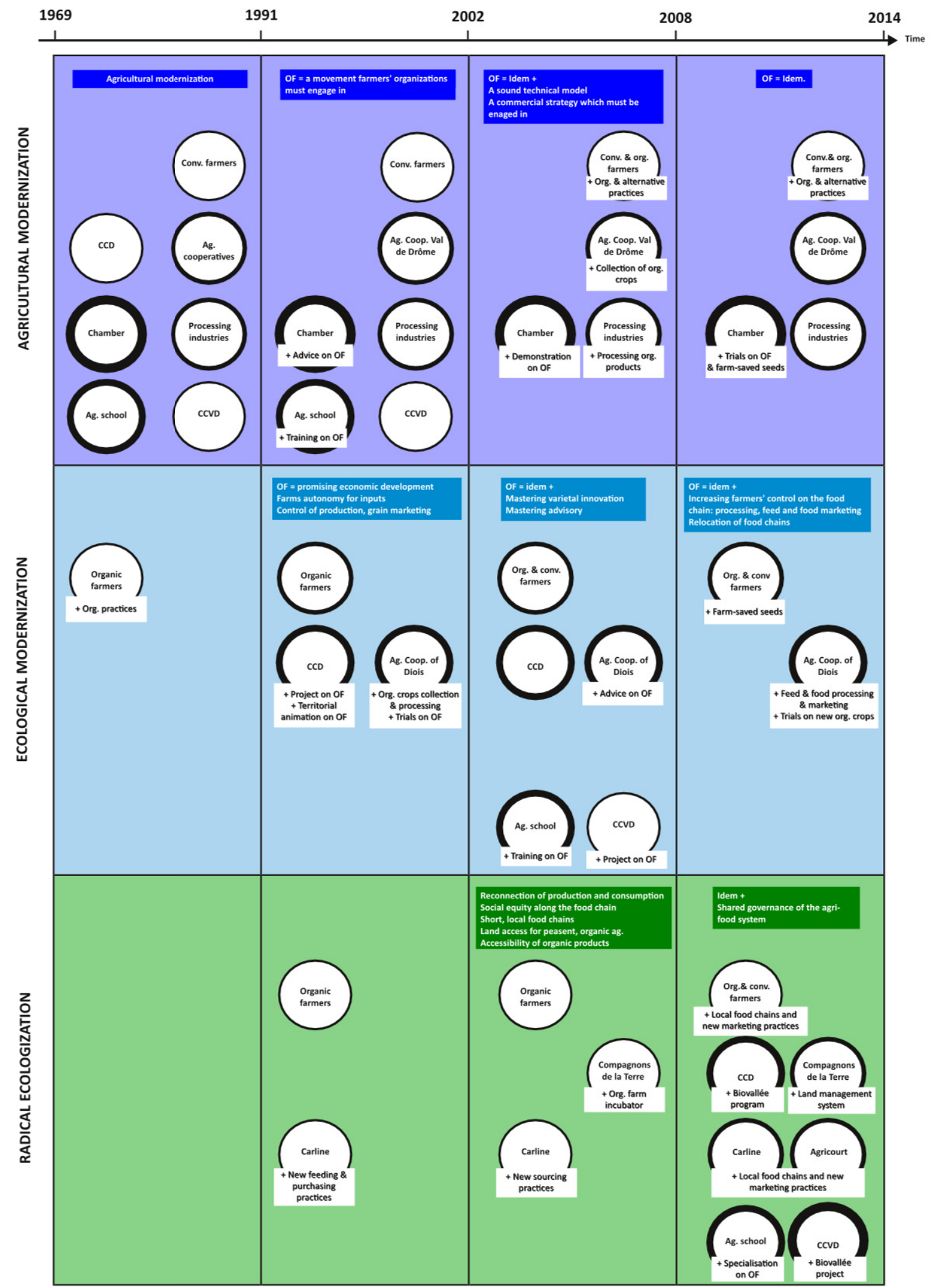

Figure 3. Co-evolution of representations, practices, and interactions within the agri-food system of the Drôme valley 1969-2015. Time is on the $x$-axis. The three horizontal bands are the paradigms. Dark colored rectangles indicate the evolving representations of agricultural issues and OF. The circles are the actors. Line thickness represents the actors' influence capacity (i.e., power). The white rectangles show the new practices that actors develop. 


\section{Discussion}

The longitudinal analysis of the local agri-food system brings evidence that, although OF still represents a minority of farmers, a profound reconfiguration of the socio-technical system (i.e., a transition) is ongoing in the Drôme valley. This transition follows a much more complex dynamic than the MLP archetype, as it results from the interaction between, not two, but three socio-technical configurations. As we will now see, accounting for this complexity allows the identification of the mechanisms that have allowed a transition to take place in this region and how actors have enacted them.

\subsection{Interessements and Enrolments Causing Regime Destabilisation and Reconfiguration}

The destabilization of the existing regime starts with the engagement of the farmers' cooperatives on a new technological trajectory and their enrolment of CCD. The representations and practices of these regime actors progressively align around a paradigm of "Ecological modernization", and these actors start considering OF as a way forward for all local agriculture. This provokes the unlocking of technical and governance regime elements, as well as beliefs, roles, and business models, identified by Turnheim and Geels [56] as signals of full destabilization. As such, these changes are significant and fundamental. These actors may, however, be considered as remaining within the regime, as neither their representations nor their novel practices and interactions challenge the dominant system-not at the beginning at least (Figure 4).



Figure 4. Three socio-technical configurations composing the agri-food system of the Drôme valley.

This is an essential first step, because some incumbent actors' visions become compatible with more radical representations, laying the foundations for further change. As they implement strategies to support the development of OF through the setting up of new forms of coordination and new practices, some actors manage to redefine their own role and to enlarge their capability within the local agri-food system: CCD becomes a legitimate stakeholder in relation to agricultural matters; the local farmers cooperatives develop advisory activities and increase their control over the supply chain. This impacts incumbents' roles: the Chamber is no longer the only local actor who can determine local agricultural policies and agendas and offer agricultural extension services. As suggested by Wittmayer et al. [28], the creation of new roles, and the alteration of existing ones, provokes regime destabilization. This destabilization leads to a transformation of the selection environment, with newly developed practices and representations being more compatible with radical innovations. As such, it is preparatory and necessary to the more profound reconfiguration provoked by the enrolment of regime actors into the alternative socio-technical configuration that fosters "Radical ecologization" (second step). As shown in Figure 5, enrolments make some actors move from the dominant socio-technical configuration to the 
others, as their practices and representations gradually evolve according to their needs, and to opportunities, and under the influence of external factors, resulting in fine to a greater number of actors in alternative configurations (Figure 5).

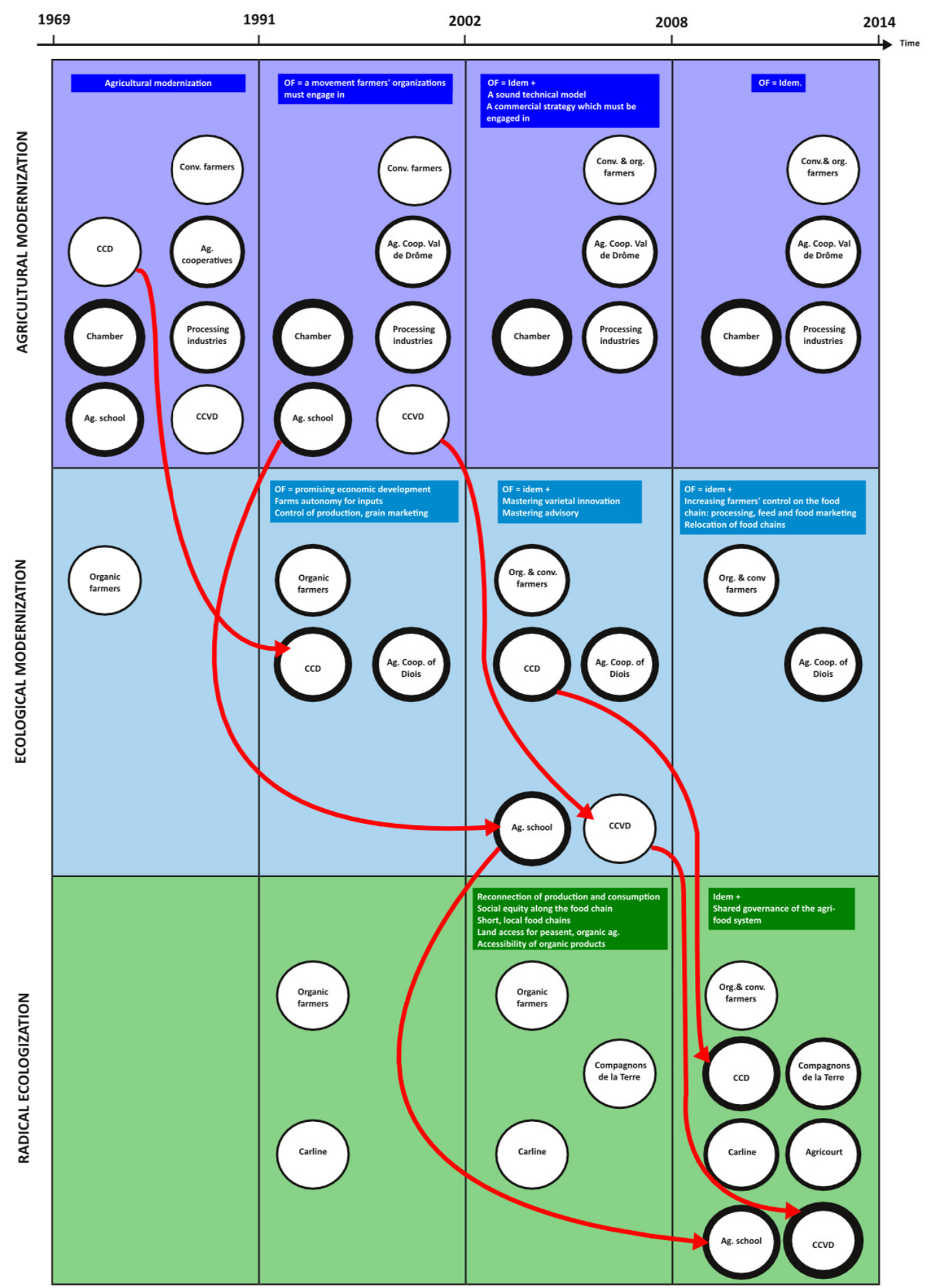

Figure 5. Circulation of actors from one socio-technical configuration to another. Time is on the $x$-axis. The three horizontal bands are the paradigms. Dark colored rectangles indicate the evolving representations of agricultural issues and OF. The circles are the actors. Line thickness represents the actors' influence capacity (i.e., power). The white rectangles show the new practices that actors develop. Red arrows show the circulation of actors from one configuration to another along time. 
Contrary to the stretch-and-transform process described by Smith and Raven [57], where a niche restructures the mainstream selection environment in ways favorable to its development, here the process is contingent and internal and does not result from a niche's deliberate action to transform the regime. The results, in line with Fuenfschilling and Truffer's [58] assumption, show that the transformation of the selection environment through the emergence, within the regime, of an alternative paradigm that niches may be congruent with, is the critical, first step of the reconfiguration process.

\subsection{Combined Effect of Multiple Niches}

Various niches interact with the regime in the recent period. As described in Section 4, each niche aggregates various elements (infrastructures, practices, representations, governance arrangements) in an alternative model and impacts various components of the local agri-food system (consumption, production, processing, marketing, research, extension, and/or public policies). For instance, Carline influences: farming practices by providing remunerating outlets for small-scale, local, organic farmers; consumption practices by giving access to organic food, often in bulk, at a reasonable price for all inhabitants of Diois; public policies by being a member of the Diois agricultural committee; market, as it developed local food chains; and symbolic meanings by building a viable, alternative economic model. However, if each niche influences various components of the socio-technical system, they each have a significant impact on only one or two components: Carline works with only a few dozen local producers but supplies a tenth of Diois' population; the phytotherapy project only involves fifteen farmers but it manages to put the topic of phytotherapy on the agenda of both the regional body for research on goat farming and the national training fund; the farm incubator has only welcomed a dozen project holders so far, but it strongly impacts access to land with the creation of a new farmland management system; Agricourt also only works with a few dozen local producers but it allows $60 \%$ of the meals served in school canteens to be made out of fresh products coming from local, small-scale, fairly remunerated farmers.

Unlike the MLP's archetypal suggestion that transitions are triggered by one-niche regime interaction, the transition ongoing in the Drôme valley is provoked by multiple niches, corresponding to distinct components of the socio-technical system, which are aligned with the same paradigm and co-exist and exert pressure, simultaneously, not in a coordinated manner but in the same direction, on the various dimensions of the regime. These results call for revisiting the MLP diagram [1], as presented in Figure 6.

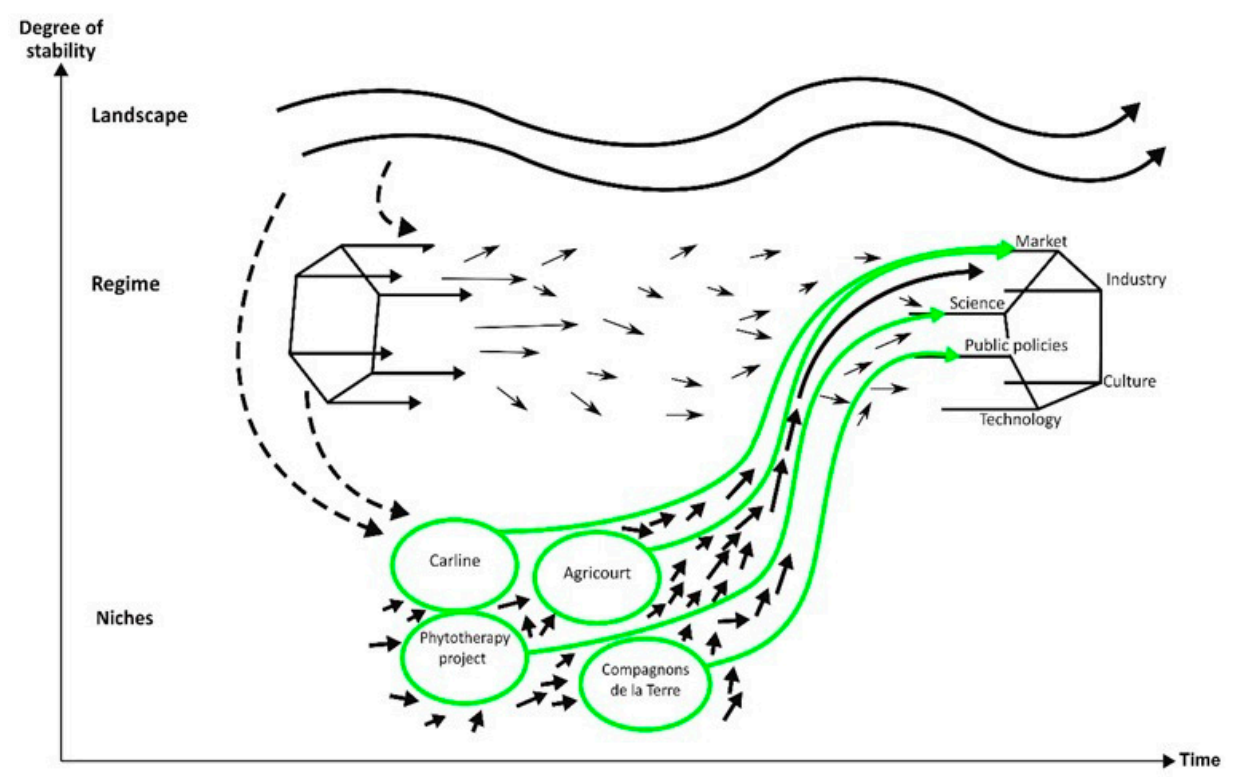

Figure 6. Revisit of Geels's (2011) diagram of the multi-level perspective. Regime reconfiguration results from interactions with multiple niches that impact its various dimensions. 


\subsection{Rebalancing of Power Relations}

The actors in line with alternative paradigms ("Ecological modernization" and "Radical ecologization") enhanced their own capabilities, which indicates that power relations have been altered. The longitudinal analysis shows that, along with the reconfiguration of the socio-technical system, a change in power relations comes about, which occurs through iterative processes of vision and practice adjustment that actors provoke through enrolment processes. In the 1990s, the alignment of more and more numerous and powerful actors with the paradigm of "Ecological modernization" forces the Chamber and the agricultural school to consider OF within their scope and to modify their activities accordingly. Deeper reconfiguration subsequently occurs through the interactions between the four niches and the regime. Within these niches, the radical nature of innovation lies beyond technology; it lies in the challenging of the organization-of the architecture, in McMeekin et al.'s words [31], of the dominant agri-food system. Agricourt and Carline both call for reconnecting producers and consumers and for defining new business practices, giving greater control of the food chain to producers and consumers. The project of the goat farmers' union designs a strategy of animal health management, which gives back to farmers the control over input production, knowledge, and prescription. Compagnons de la Terre acts to widen the management of farmland to civil society and local authorities, facilitating the setting up of atypical entrants in farming. In these niches, actors do not develop technological novelties; they develop radically new visions of what should be the relevant network of actors, and accordingly, new forms of coordination and governance. As suggested by Rossi et al. [27], they are enabling relational environments where power reconfiguration occurs and transformative power [24] develops. The enrolment of local authorities is critical as it prompts niche actors to develop an even more integrated vision of the role of agriculture in local development and of the desirable form(s) of governance. It additionally enables these visions to become a structuring element of the local agri-food system. Consequently, existing governance networks (the network of actors managing farmland, the experimentation network for goat farming, and the governance bodies of local food chains) are influenced or complemented accordingly. This results in the widening of the governance of the agri-food system to include actors who were previously excluded, e.g., small-scale farmers and non-agricultural actors, such as civil society, consumers, and local authorities, and in the weakening of the Chamber.

These findings suggest that the local scale allowed overcoming lock-in effects that predominate at broader scales by facilitating the formation of ground-breaking collaborations (the inter-cooperative project, the multi-actor niche-networks) and articulating complementary perimeters of action. This important topic needs deeper elaboration, which will be provided in another article.

\section{Conclusions}

The analytical approach developed in this paper allows exploration of the sociopolitical dimension of whole system reconfigurations and hence highlights novel aspects of agency in transitions. The analysis of the system reconfiguration processes at stake in the Drôme valley sheds light on the way actors created and activated levers for a sustainability transition of the local agri-food system. It points to three main mechanisms that allowed a regime shift to come about: (1) the emergence and development of an alternative socio-technical configuration within the regime; (2) the combined effect of multiple niche-innovations that impact the various components of the socio-technical system, simultaneously and in the same direction; and (3) the rebalancing of power relations and the redesign of local agri-food governance resulting from the interactions between these niches and the alternative configuration within the regime. It shows that these mechanisms were enacted by actors through enrolment and interessement processes, and stresses the importance of spill-over effects. These findings challenge the assumption commonly underlying research on agency in transitions that profound changes at the 
regime level are intentionally enacted by actors who have an interest in changing the regime, who build alliances and implement strategies to that end.

These results build on and articulate various previous contributions from transition studies, thereby confirming the strength of the MLP heuristic. They reinforce the view that accounting for multiple regime dynamics and multiple niche-regime interactions is critical to develop further understanding of transition processes [29]. They contribute to a further characterization of regime destabilization processes and of the incremental system improvements required to foster sustainability transitions [30]. They also suggest that transitions require more than single niche scaling-up or niche accumulation processes. They stress the importance of the emergence of an alternative paradigm within the regime and the role of multiple, unrelated niches impacting the various dimensions of the agri-food system simultaneously. From a transformative perspective, these results suggest that transitions may be fostered by: (1) supporting the diffusion of an alternative technological paradigm within the regime that niches may be congruent with; (2) creating the conditions to stimulate the coexistence and development of a diversity of radical innovations relating to all the various components of the socio-technical system; and (3) moving from a technologydriven approach of innovation towards an emphasis on organizational innovations that foster the rebalancing of power relations.

By showing the paramount importance, in this transition process, of the change in power relations that occurred chiefly through linking agricultural issues to wider socioeconomic and political issues_-such as fairness, multi-stakeholder decision-making, community life - the present analysis challenges the assertion that a comprehensive understanding of system reconfiguration can be developed with approaches focusing primarily on environmental sustainability, without tackling "wider socio-economic problems such as poverty, inequality, problems in democratic accountability" [59]. It calls for the embracing of a systemic view of sustainability in transition studies, so as to shed light on, investigate, and question the foundational socio-economic and political dimensions of incumbent sociotechnical systems and develop a better understanding of their reconfiguration processes.

One important limitation of this research is that it is based on the empirical analysis of a single, local case. This raises the question of the generic nature of its results, particularly given the strong specificities of this case (not a highly productive area, presence of many agricultural productions and chains, long-term inter-municipalities dynamics). Further research could investigate the genericity of the results by looking at other regional dynamics. The spatial dimension of the studied processes would also deserve a profound analysis $[60,61]$, which will be developed in another paper.

Funding: This research was funded by INRA and Rhône-Alpes Region, and benefited from financial support from Dynrurabio (ANR-10-STRA-0009) and Era-Net HealthyGrowth projects.

Institutional Review Board Statement: Not applicable.

Informed Consent Statement: Not applicable.

Data Availability Statement: The data presented in this study are available in [48].

Acknowledgments: I thank Elisabeth Lecrivain, Marc Vincent, and Julia Tual for sharing interviews and Ionara Costa and Claire Lamine for reviewing this article. I also thank anonymous reviewers for very elaborate, useful, and thoughtful comments. A previous version of this paper was presented at IST 2018.

Conflicts of Interest: The author declares no conflict of interest.

\section{References}

1. Geels, F.W. The Multi-Level Perspective on Sustainability Transitions: Responses to Seven Criticisms. Environ. Innov. Soc. Transit. 2011, 1, 24-40. [CrossRef]

2. Geels, F.W. Technological Transitions as Evolutionary Reconfiguration Processes: A Multi-Level Perspective and a Case-Study. Res. Policy 2002, 31, 1257-1274. [CrossRef]

3. Geels, F.W.; Schot, J. Typology of Sociotechnical Transition Pathways. Res. Policy 2007, 36, 399-417. [CrossRef] 
4. Rip, A.; Kemp, R. Technological Change. In Human Choice and Climate Change: Resources and Technology; Rayner, S., Malone, E.L., Eds.; Battelle Press: Columbus, OH, USA, 1998; Volume 2.

5. Kern, F.; Smith, A. Restructuring Energy Systems for Sustainability? Energy Transition Policy in the Netherlands. Energy Policy 2008, 36, 4093-4103. [CrossRef]

6. Rogge, K.S. OECD (2015) System Innovation: Synthesis Report. Environ. Innov. Soc. Transit. 2017, 22, 90-91. [CrossRef]

7. Berkhout, F.; Smith, A.; Stirling, A. Socio-Technological Regimes and Transition Contexts. In System Innovation and the Transition to Sustainability: Theory, Evidence and Policy; Edward Elgar Publishing: Cheltenham, UK, 2004; pp. 48-75.

8. Shove, E.; Walker, G. Caution! Transitions Ahead: Politics, Practice and Transition Management. Environ. Plan. A 2007, 39, 763-770. [CrossRef]

9. Genus, A.; Coles, A.-M. Rethinking the Multi-Level Perspective of Technological Transitions. Res. Policy 2008, 37, 1436-1445. [CrossRef]

10. Smith, A.; Stirling, A.; Berkhout, F. The Governance of Sustainable Socio-Technical Transitions. Res. Policy 2005, 34, 1491-1510. [CrossRef]

11. Giddens, A. La Constitution de La Société; PUF: Paris, France, 1987; Volume 19841.

12. Elzen, B.; Geels, F.W.; Leeuwis, C.; van Mierlo, B. Normative Contestation in Transitions 'in the Making': Animal Welfare Concerns and System Innovation in Pig Husbandry. Res. Policy 2011, 40, 263-275. [CrossRef]

13. Geels, F.W.; Verhees, B. Cultural Legitimacy and Framing Struggles in Innovation Journeys: A Cultural-Performative Perspective and a Case Study of Dutch Nuclear Energy (1945-1986). Technol. Forecast. Soc. Chang. 2011, 78, 910-930. [CrossRef]

14. Lamine, C.; Navarrete, M.; Cardona, A. Transitions towards organic farming at the farm and at the local scales: The role of innovative production and organisational modes and networks. In Organic Farming, Prototype for Sustainable Agricultures; Springer: Cham, Switzerland, 2014; pp. 423-438.

15. Hargreaves, T.; Hielscher, S.; Seyfang, G.; Smith, A. Grassroots Innovations in Community Energy: The Role of Intermediaries in Niche Development. Glob. Environ. Chang. 2013, 23, 868-880. [CrossRef]

16. Seyfang, G.; Haxeltine, A. Growing Grassroots Innovations: Exploring the Role of Community-Based Initiatives in Governing Sustainable Energy Transitions. Environ. Plan. C Gov. Policy 2012, 30, 381-400. [CrossRef]

17. Fischer, L.-B.; Newig, J. Importance of Actors and Agency in Sustainability Transitions: A Systematic Exploration of the Literature. Sustainability 2016, 8, 476. [CrossRef]

18. De Haan, F.J.; Rotmans, J. A Proposed Theoretical Framework for Actors in Transformative Change. Technol. Forecast. Soc. Chang. 2018, 128, 275-286. [CrossRef]

19. Farla, J.C.M.; Markard, J.; Raven, R.; Coenen, L. Sustainability Transitions in the Making: A Closer Look at Actors, Strategies and Resources. Technol. Forecast. Soc. Chang. 2012, 79, 991-998. [CrossRef]

20. Späth, P.; Rohracher, H. 'Energy Regions': The Transformative Power of Regional Discourses on Socio-Technical Futures. Res. Policy 2010, 39, 449-458. [CrossRef]

21. Meadowcroft, J. Engaging with the Politics of Sustainability Transitions. Environ. Innov. Soc. Transit. 2011, 1, 70-75. [CrossRef]

22. Smith, A.; Stirling, A. The Politics of Social-Ecological Resilience and Sustainable Socio-Technical Transitions. Ecol. Soc. 2010, 15, 11. [CrossRef]

23. Grin, J.; Rotmans, J.; Schot, J. On Patterns and Agency in Transition Dynamics: Some Key Insights from the KSI Programme. Environ. Innov. Soc. Transit. 2011, 1, 76-81. [CrossRef]

24. Avelino, F. Power in Sustainability Transitions: Analysing Power and (Dis)Empowerment in Transformative Change towards Sustainability. Environ. Policy Gov. 2017, 27, 505-520. [CrossRef]

25. Geels, F.W. Regime Resistance against Low-Carbon Transitions: Introducing Politics and Power into the Multi-Level Perspective. Theory Cult. Soc. 2014, 31, 21-40. [CrossRef]

26. Avelino, F.; Wittmayer, J.M. Shifting Power Relations in Sustainability Transitions: A Multi-Actor Perspective. J. Environ. Policy Plan. 2016, 18, 628-649. [CrossRef]

27. Rossi, A.; Bui, S.; Marsden, T. Redefining power relations in agri-food systems. J. Rural Stud. 2019. [CrossRef]

28. Wittmayer, J.M.; Avelino, F.; van Steenbergen, F.; Loorbach, D. Actor Roles in Transition: Insights from Sociological Perspectives. Environ. Innov. Soc. Transit. 2017, 24, 45-56. [CrossRef]

29. Geels, F.W. Disruption and Low-Carbon System Transformation: Progress and New Challenges in Socio-Technical Transitions Research and the Multi-Level Perspective. Energy Res. Soc. Sci. 2018, 37, 224-231. [CrossRef]

30. Geels, F.W. Low-Carbon Transition via System Reconfiguration? A Socio-Technical Whole System Analysis of Passenger Mobility in Great Britain (1990-2016). Energy Res. Soc. Sci. 2018, 46, 86-102. [CrossRef]

31. McMeekin, A.; Geels, F.W.; Hodson, M. Mapping the Winds of Whole System Reconfiguration: Analyzing Low-Carbon Transformations across Production, Distribution and Consumption in the UK Electricity System (1990-2016). Res. Policy 2019, 48, 1216-1231. [CrossRef]

32. Smith, A.; Voss, J.-P.; Grin, J. Innovation Studies and Sustainability Transitions: The Allure of the Multi-Level Perspective and Its Challenges. Res. Policy 2010, 39, 435-448. [CrossRef]

33. Avelino, F. Power in Transition: Empowering Discourses on Sustainability Transitions; Erasmus University Rotterdam: Rotterdam, The Netherlands, 2011. 
34. Schot, J.; Kanger, L. Deep Transitions: Emergence, Acceleration, Stabilization and Directionality. Res. Policy 2018, 47, 1045-1059. [CrossRef]

35. Elzen, B.; van Mierlo, B.; Leeuwis, C. Anchoring of Innovations: Assessing Dutch Efforts to Harvest Energy from Glasshouses. Environ. Innov. Soc. Transit. 2012, 5, 1-18. [CrossRef]

36. Pinch, T.J.; Bijker, W.E. The Social Construction of Facts and Artefacts: Or How the Sociology of Science and the Sociology of Technology Might Benefit Each Other. Soc. Stud. Sci. 1984, 14, 399-441. [CrossRef]

37. Geels, F. From Sectoral Systems of Innovation to Socio-Technical Systems-Insights about Dynamics and Change from Sociology and Institutional Theory. Res. Policy 2004, 33, 897-920. [CrossRef]

38. Belz, F.M. A Transition towards Sustainability in the Swiss Agri-Food Chain (1970-2000): Using and Improving the Multi-Level Perspective. In System Innovation and the Transition to Sustainability; Elzen, B., Geels, F.W., Green, K., Eds.; Edward Elgar Publishing: Cheltenham, UK, 2004; pp. 97-114. [CrossRef]

39. Smith, A. Green Niches in Sustainable Development: The Case of Organic Food in the United Kingdom. Environ. Plan. C Gov. Policy 2006, 24, 439-458. [CrossRef]

40. Callon, M.; Law, J. On Interests and Their Transformation: Enrolment and Counter-Enrolment. Soc. Stud. Sci. 1982, 12, 615-625. [CrossRef]

41. Geels, F.W. Ontologies, Socio-Technical Transitions (to Sustainability), and the Multi-Level Perspective. Res. Policy 2010, 39, 495-510. [CrossRef]

42. Bui, S.; Cardona, A.; Lamine, C.; Cerf, M. Sustainability Transitions: Insights on Processes of Niche-Regime Interaction and Regime Reconfiguration in Agri-Food Systems. J. Rural Stud. 2016, 48, 92-103. [CrossRef]

43. Diaz, M.; Darnhofer, I.; Darrot, C.; Beuret, J.-E. Green Tides in Brittany: What Can We Learn about Niche-Regime Interactions? Environ. Innov. Soc. Transit. 2013, 8, 62-75. [CrossRef]

44. Latour, B. Where Are the Missing Masses? The Sociology of a Few Mundane Artifacts. In Shaping Technology-Building Society. Studies in Sociotechnical Change; Bijker, W., Law, J., Eds.; MIT Press: Cambridge, MA, USA, 1992.

45. Callon, M. Some Elements of a Sociology of Translation: Domestication of the Scallops and the Fishermen of St Brieuc Bay. Sociol. Rev. 1984, 32, 196-233. [CrossRef]

46. Lawhon, M.; Murphy, J.T. Socio-Technical Regimes and Sustainability Transitions: Insights from Political Ecology. Prog. Hum. Geogr. 2012, 36, 354-378. [CrossRef]

47. Hamel, J. Savoir Écrire En Sociologie: Et Dans Les Sciences Sociales; Les Presses de l'Université de Montréal: Montreal, QC, Canada, 2018.

48. Bui, S. Pour Une Approche Territoriale Des Transitions Écologiques. Analyse de La Transition Vers L'agroécologie Dans La Biovallée (1970-2015); AgroParisTech: Paris, France, 2015.

49. Polo, M.; Veyron, M. L'agriculture Biologique Dans La Drôme. Evolution Depuis 10 Ans. Problèmes Techniques Des Agriculteurs; ISARA: Lyon, France, 1982; Volume 2, 100p.

50. Barrès, D.; Bonny, S. Une Ethique de La Pratique Agricole: Agriculteurs Biologiques Du Nord-Drôme; INRA: Paris, France, 1986.

51. Hervieu, B.; Léger, D. Le Retour à La Nature: Au Fond de La Forêt, l'État; Le Seuil: Paris, France, 1979.

52. Goodman, D. Rural Europe Redux? Reflections on Alternative Agro-Food Networks and Paradigm Change. Sociol. Rural. 2004, 44, 3-16. [CrossRef]

53. Duffaud-Prévost, M.-L. Construire un ancrage territorial: Le cas des entreprises de produits cosmétiques et de phytothérapie dans la vallée de la Drôme. Pour 2016, 229, 149-157. [CrossRef]

54. Hughes, T.P. Networks of Power: Electrification in Western Society, 1880-1930; JHU Press: Baltimore, MD, USA, 1983.

55. Koulytchizky, S.; Mauget, R. Le Développement Des Groupes Coopératifs Agricoles Depuis Un Demi-Siècle: A La Recherche d'un Nouveau Paradigme. Rev. Int. Écon. Soc. Recma 2003, 287, 14-40. [CrossRef]

56. Turnheim, B.; Geels, F.W. The Destabilisation of Existing Regimes: Confronting a Multi-Dimensional Framework with a Case Study of the British Coal Industry (1913-1967). Res. Policy 2013, 42, 1749-1767. [CrossRef]

57. Smith, A.; Raven, R. What Is Protective Space? Reconsidering Niches in Transitions to Sustainability. Res. Policy 2012, 41, 1025-1036. [CrossRef]

58. Fuenfschilling, L.; Truffer, B. The Structuration of Socio-Technical Regimes-Conceptual Foundations from Institutional Theory. Res. Policy 2014, 43, 772-791. [CrossRef]

59. Geels, F.W.; McMeekin, A.; Mylan, J.; Southerton, D. A Critical Appraisal of Sustainable Consumption and Production Research: The Reformist, Revolutionary and Reconfiguration Positions. Glob. Environ. Chang. 2015, 34, 1-12. [CrossRef]

60. Coenen, L.; Benneworth, P.; Truffer, B. Toward a Spatial Perspective on Sustainability Transitions. Res. Policy 2012, 41, 968-979. [CrossRef]

61. Levin-Keitel, M.; Mölders, T.; Othengrafen, F.; Ibendorf, J. Sustainability Transitions and the Spatial Interface: Developing Conceptual Perspectives. Sustainability 2018, 10, 1880. [CrossRef] 